\title{
Live Weight Changes and Their Relationship with the Ovarian Status of Maiden Fat-Tailed Barbarine Ewes
}

\author{
Imēne Ben Salem ${ }^{1}$, Mourad Rekik ${ }^{1^{*}}$, Mohammed Ben Hamouda ${ }^{2}$ \\ and Narjess Lassoued ${ }^{3}$
}

\author{
${ }^{1}$ Ecole Nationale de Médecine Vétérinaire, 2020 Sidi Thabet, Tunisia \\ ${ }^{2}$ Institution de la Recherche et de l'Enseignement Supérieur Agricoles, \\ 30 Rue Alain Savary, 2020, Tunis, Tunisie \\ 3INRA-Tunisie, Laboratoire des Productions Animales et Fourragères, \\ Rue Hédi Karray, 2049 Ariana, Tunisia
}

التغيرات في وزن الجسم وعلاقتها بحالة المبيض في إناث الضأن البربري متضخم الذيل العذراء

أ. بن سالم و مراد الرقيق و م. بن حمودة و نرجس الأسود

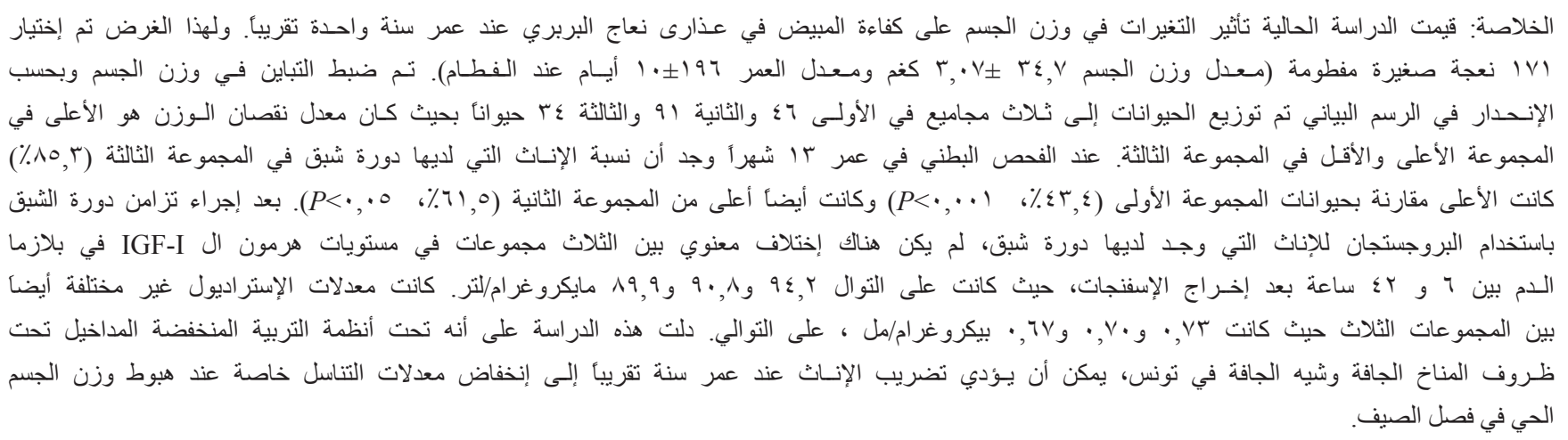

ABSTRACT: The current study assessed the effect of the pattern of live weight change on the ovarian function of maiden Barbarine ewes at approximately 1 year of age. For this purpose, a total of 171 weaned ewe lambs (mean live weight \pm s.d. $34.7 \pm 3.07 \mathrm{~kg}$ and mean age \pm SD $196 \pm 10$ days at weaning) were selected for the experiment. Adjustment of live weight variation was used. Based on the slope of the curve, animals were grouped into three classes LWCI $(n=46)$, LWCII $(n=91)$ and LWCIII $(n=34)$ with live weight loss being highest in LWCI and lowest in LWCIII. Following laparoscopy at 13 months of age, the proportion of ewe lambs found cycling in LWCIII (85.3\%) was higher in comparison to animals in LWCI $(43.4 \% ; P<0.001)$ and tended to be superior to those in LWCII $(61.5 \% ; P<0.05)$. Following synchronisation with progestagen of the females found cycling, levels of plasma IGF-I concentrations between 6 and 42 hrs after removal of sponges were not significantly different between the three classes of live weight, and respectively averaged $94.2,90.8$ and $89.8 \mu \mathrm{g} / \mathrm{l}$ for LWCI, LWCII and LWCIII females. Levels of estradiol were also not significantly different between the three groups $(0.73,0.70$ and 0.67 $\mathrm{pg} / \mathrm{ml}$ for LWCI, LWCII and LWCIII ewe lambs, respectively). It was concluded that, in low input systems of semi-arid and arid Tunisia, mating ewe lambs at the approximate age of 1 year is likely to lead to depressed reproductive performance particularly when the summer live weight-loss is elevated.

Keywords: Maiden ewes, live weight, ovarian activity, IGF-I, estradiol.

\section{Introduction}

The main sheep-mating system in Tunisia and in several other regions of West Asia and North Africa is the one where the ewes are mated in spring to lamb in autumn. For those ewe lambs that are selected as replacement stock, they attain puberty when they are about 10 to 12 months of age, corresponding to late summer-early autumn and then elapse into anoestrus before they are mated at 18 months for the first time (Khaldi, 1984). Breeding ewe lambs when they attain puberty is not a common practice in Tunisia although Rekik and Gharbi (1999) and Rekik et al. (2002) have shown that 
acceptable results of fertility can be obtained if ewe lambs of the autochthonous Barbarine and Queue Fine de l'Ouest breeds receive supplementary feeding to achieve higher live weights or are hormonally treated by a combination of progestagens and equine chorionic gonadotropin. In such a type of dry Mediterranean production conditions, Martin et al. (1999) postulated that summer losses in live weight of the animals can have a negative effect in their ability to reproduce with satisfactory rates.

The hypothesis proposed is that under semi-arid conditions of central Tunisia, several changes in live weight occur from the time replacement ewe lambs are selected until their attain puberty during late summer. This study therefore aimed to investigate the effect of live weight changes on the ovarian status and functioning of approximately 1 year-old Barbarine ewes.

\section{Materials and Methods}

\section{Study Location and Animals}

The experiment was carried out between April and November 2005 at the Office de l'Elevage et des Pâturages farm of Jebibina (Central Tunisia). The region is semi-arid with an average annual rainfall of $390 \mathrm{~mm}$ and its latitude is $35^{\circ} \mathrm{N}$. It experiences a Mediterranean climate with cool winters and hot dry summers.

On April the $20^{\text {th }} 2005$ (spring), a total of 171 weaned ewe lambs of the Barbarine breed selected as replacement stock (mean live weight \pm s.d. $34.7 \pm 3.07 \mathrm{~kg}$ and mean age \pm s.d. $196 \pm 10$ days at weaning) were kept for the experiment. From weaning until the age of 13 months the animals were run in a single flock isolated from the rams by at least $1.5 \mathrm{~km}$ and housed in fully open sheds.

\section{Nutritional and Health Management}

Throughout the experimental period, the animals were allowed to graze poor pastures of the native Medicago spp. or spontaneous Graminaceae in spring and fall or cereal stubbles in summer for approximately $7 \mathrm{hrs}$ a day. From early June until the end of the experiment in November; the animals were supplemented with $0.2 \mathrm{~kg} /$ ewe lamb/day of a soybean meal-barley-based concentrate supplement containing $12.3 \mathrm{MJ}$ of metabolisable energy (ME)/kg dry matter (DM), $156 \mathrm{~g}$ crude protein (CP)/kg DM and a DM concentration of $871 \mathrm{~g} / \mathrm{kg}$ and also received $0.8 \mathrm{~kg}$ hay per ewe per day (containing 6.41 MJ of ME/kg DM, $80 \mathrm{~g} \mathrm{CP} /$ $\mathrm{kg}$ DM, and $309 \mathrm{~g}$ crude fibre/kg DM; DM concentration: $885 \mathrm{~g} / \mathrm{kg}$ ). At the approximate age of 8 months, animals were drenched against internal parasites using Oxfendazol at a conventional dose of $5 \mathrm{mg} / \mathrm{kg}$ body weight.

\section{Live Weight Variation}

From weaning until the age of 13 months, live weight of the ewe lambs was measured every 2 weeks at $08.00 \mathrm{hrs}$ before grazing. The gamma model of Wood (1967) was used to describe lactation curves (SAS, 1991; NewtonRaphson NLIN procedure). In this study, the portion of the curve separating the recorded first average live weight at weaning (196 days of age) and the lowest average live weight at the end of the summer season corresponding to an average age of 395 days (13 months). The equation describing the gamma function is:

$$
y_{n}=a n^{b} e^{-c n}
$$

where $y_{n}$ is the live weight on age $n$; $a$ is a scaling factor to represent live weight at weaning; and $b$ and $c$ are factors associated with the inclining and the declining slopes of the live weight variation curve. The slope of the curve designated $\mathrm{s}$ and which stands for persistency in the description of the lactation curves is calculated as being $\mathrm{s}=$ $-(b+1) \ln (c)$, and was used here to describe the intensity of live weight loss in the declining portion of the curve.

The average squared multiple correlation coefficient $\left(\mathrm{R}^{2}\right)$ of the log-transformed gamma function was $0.99 \pm 0.006$. Average $\mathrm{s}( \pm \mathrm{s} . \mathrm{d})$ as computed from the gamma function was $8.72 \pm 0.57$ and higher values of $\mathrm{s}$ indicated lower loss of live weight. Based on this parameter, the ewe lambs were grouped in three classes of live weight: LWCI ewe lambs $(n=46)$ with a value of $\mathrm{s}<$ mean s-s.d/2, LWCII ewe lambs $(\mathrm{n}=91)$ with a value of s comprised between mean s-s.d./2 and mean s+s.d./2 and LWCIII ewe lambs $(n=34)$ with a value of $s>$ mean $\mathrm{s}+$ s.d./2. Average respective values of $\mathrm{s}$ were $8.14 \pm 0.33$, $8.68 \pm 0.16$ and $9.58 \pm 0.52$ for ewe lambs in LWCI, LWCII and LWCIII $(P<0.001)$. Patterns of live weight changes from weaning until the age of 13 months according to the class of live weight are shown in Figure 1.

\section{Reproductive Characteristics at 1 Year of Age}

In November 2005, when the ewe lambs were aged 13 months, they were subjected to laparoscopy for the determination of the ovarian status. Laparoscopy was carried out according to the method described by Thimonier and Mauléon (1969). The animals found cycling in the three classes of live weight had their oestrous cycles synchronised using intravaginal progesterone pessaries impregnated with $40 \mathrm{mg}$ fluorogestone acetate and left in situ for 14 days. At pessaries removal and for the subsequent $42 \mathrm{hrs}$, blood samples were recovered in heparinised vacutainer tubes from each animal. After centrifugation (3000 rpm, $15 \mathrm{~min}$.), plasma was stored at $-20^{\circ} \mathrm{C}$ until assayed for Insulin-like growth factor-I (IGF-I) and estradiol. Eleven days after the removal of pessaries, the ewe lambs were again subjected to laparoscopy as described above and the age of the corpora lutea (CL) was determined based on their size and colour as described by Oldham and Lindsay (1980). 


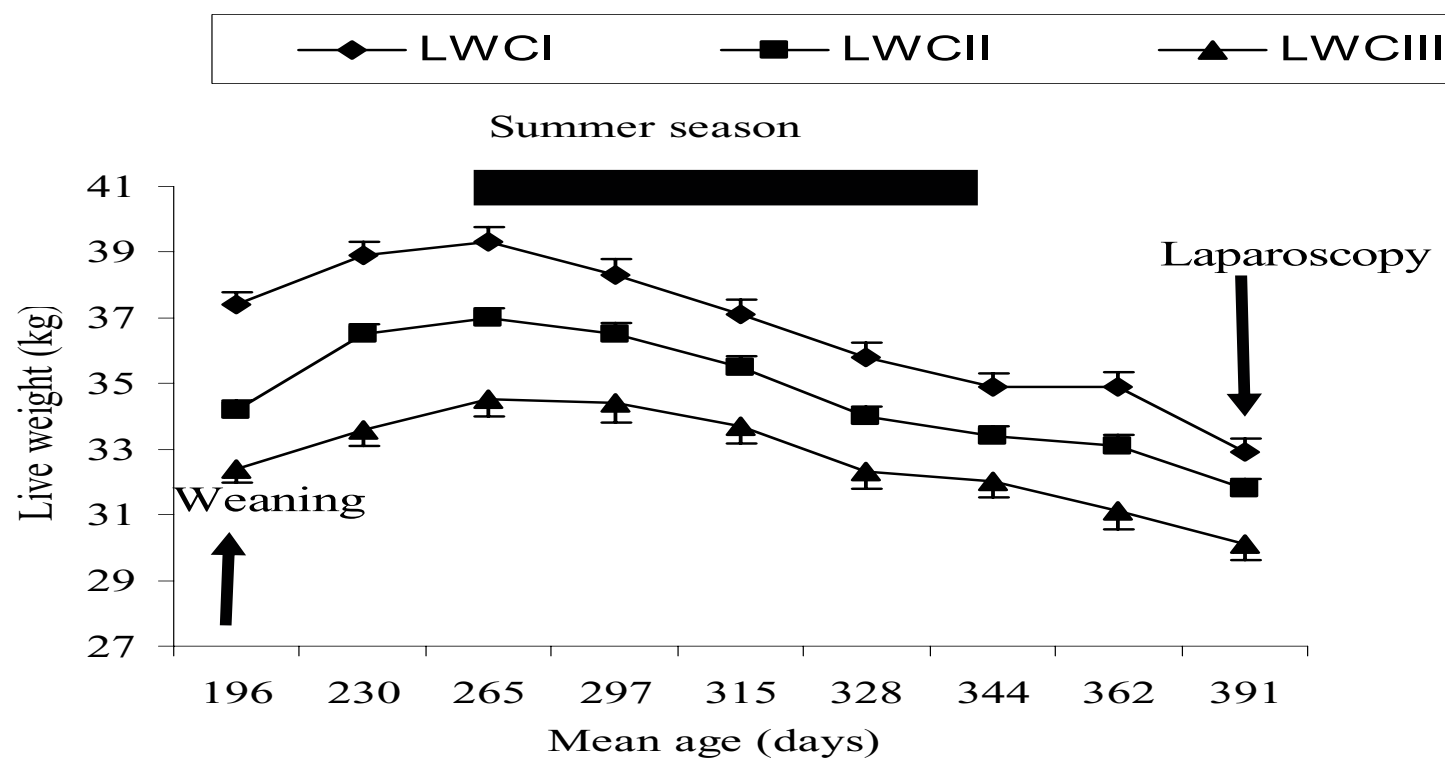

Figure 1. Live weight variation of ewe lambs per class of live weight.

\section{IGF-I and Estradiol Immunoassays}

IGF-I concentrations in plasma were assayed using a two-site immunoenzymometric kit (IEMA) OCTEIA ${ }^{\circledR}$ IGF-1 (Immunodiagnostic Systems Limited, UK) which was validated for use in sheep by Elmes et al. (2005). The method incorporates a sample pre-treatment to avoid interference from binding proteins. The limit of detection was $1.9 \mu \mathrm{g} / \mathrm{l}$. Measurement of the absorbance of each well was performed at $450 \mathrm{~nm}$ (reference $650 \mathrm{~nm}$ ) using a microplate reader (Multiskan Ascent, Thermo Labsystems, Finland). Coefficients of variation between assays were $9 \%$ and $7 \%$ for respectively a low $(52.6 \mu \mathrm{g} / \mathrm{l})$ and a high controls $(235.1 \mu \mathrm{g} / \mathrm{l})$. The coefficient of variation within assay was $2.7 \%$. Cross-reactivity with IGF-II, insulin and proinsulin was negligible. Estradiol concentrations were measured in one single assay using the Spectria radioimmunoassay kit (Orion Diagnostic Corp., Espoo, Finland), as described by Romeu et al. (1995) and adapted for use in ovine plasma (Gonzalez-Bulnes et al., 2003). Sensitivity for estradiol was $0.5 \mathrm{pg} / \mathrm{ml}$ and the intra-assay variation coefficient was $6.6 \%$.

\section{Statistical Analyses}

Data on IGF-I and estradiol concentrations were tested by repeated-measures analysis of variance using the statistical programme SAS (1991) with the class of live weight as the main effect. When the class of live weight was significant, mean treatment groups were compared according to the null-hypothesis by the least-square means option (SAS, 1991). Data on the proportions of ewes cycling at 13 months of age were analysed using a $\chi^{2}$ test. The effect of the class of live weight was considered significant when the level of probability was $5 \%$ or less.

\section{Results}

Following laparoscopy at the approximate age of 13 months, the proportion of ewe lambs found cycling in LWCIII $(29 / 34=85.3 \%)$ was higher in comparison to the same proportion in LWCI $(P<0.001)$ and in LWCII $(P<0.05$; Figure 2). Between LWCI and LWCII, these proportions (43.4 and $61.5 \%)$ tended $(P=0.07)$ to be different.

Based on the appearance of the CL at the time of laparoscopy, carried out eleven days after the removal of sponges, all the ewe lambs had ovulated and were bearing one CL each aged 6 to 7 days.

Levels of plasma IGF-I concentrations between 6 and 42 hours after removal of sponges (Table 1) were not different between animals in the three classes of live weight $(P>0.05)$. In addition, no effect of sampling time on IGF-I levels was found within LWCII. In contrast, significant differences occurred for LWCI and LWCIII where the lowest levels reached were respectively $85.9 \pm 5.47 \mu \mathrm{g} / \mathrm{l}$ at $18 \mathrm{hrs}$ and $71.0 \pm 7.43 \mu \mathrm{g} / \mathrm{l}$ at $24 \mathrm{hrs}$ after sponges' removal. For animals in both classes, the highest level $106 \mu \mathrm{g} / \mathrm{l}$ was reached at 30 and $42 \mathrm{hrs}$ after sponges' removal for respectively ewe lambs in LWCIII and LWCI.

Between 6 and 42 hrs following sponge removal, mean levels of estradiol were $0.73,0.70$ and 0.67 (s.e.m. $0.09) \mathrm{pg} / \mathrm{ml}$ for ewe lambs in respectively LWCI, LWCII and LWCIII. Estradiol levels increased sharply in animals of the LWCI at approximately $30 \mathrm{hrs}(1.60 \pm 0.32 \mathrm{pg} / \mathrm{ml})$ and were higher $(P<0.05)$ than the concentrations of ewe lambs in other live weight classes (Figure 3). During other sampling times, changes in estradiol plasma concentrations did not reach statistical significance. 


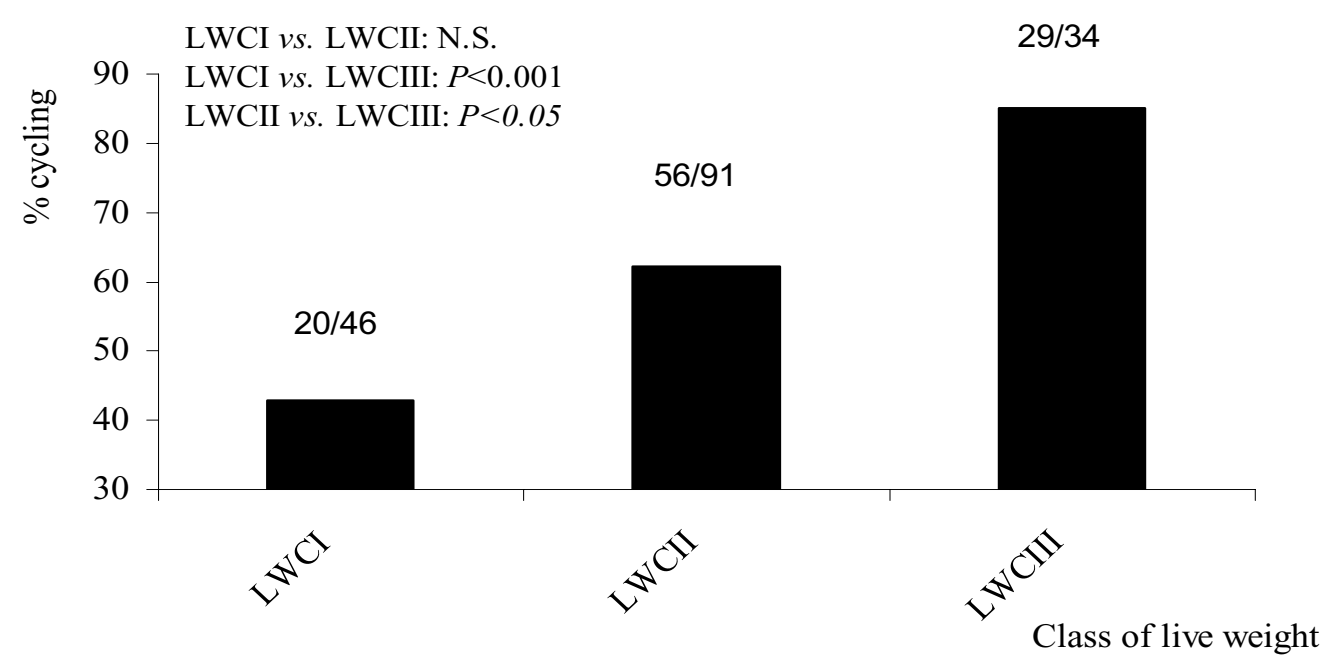

Figure 2. The effect of class of live weight on the proportion of ewe lambs found cyclingat 13 months of age.

Table 1. The effect of class of live weight on IGF-I concentrations in $\mu \mathrm{g} / 1$ ( \pm \pm s.e.m.) at different sampling times after sponges removal.

\begin{tabular}{|c|c|c|c|c|}
\hline \multirow{2}{*}{ Sampling time (hours) } & \multicolumn{3}{|c|}{ Class of Live Weight } & \multirow{2}{*}{ Significance $(P>\mathrm{F})$} \\
\hline & LWCI $(n=20)$ & LWCII ( $\mathrm{n}=56)$ & LWCIII $(\mathrm{n}=29)$ & \\
\hline 6 & $100.2 \pm 7.25$ & $89.2 \pm 6.49$ & $91.9 \pm 6.84$ & 0.52 \\
\hline 12 & $91.6 \pm 5.57$ & $87.8 \pm 4.98$ & $94.7 \pm 5.25$ & 0.63 \\
\hline 18 & $85.9 \pm 5.47$ & $94.3 \pm 4.89$ & $89.4 \pm 5.15$ & 0.52 \\
\hline 24 & $90.1 \pm 7.88$ & $89.1 \pm 7.05$ & $71.0 \pm 7.43$ & 0.15 \\
\hline 30 & $96.1 \pm 7.49$ & $96.4 \pm 6.70$ & $106.8 \pm 7.06$ & 0.48 \\
\hline 36 & $89.2 \pm 6.79$ & $86.9 \pm 6.07$ & $84.6 \pm 6.40$ & 0.88 \\
\hline 42 & $106.7 \pm 6.80$ & $92.2 \pm 6.09$ & $89.6 \pm 6.42$ & 0.17 \\
\hline
\end{tabular}

\section{Discussion}

Two main findings emerged from this study. Firstly, the rate of loss of live weight during summer time and not the absolute weight is the main cause explaining the proportion of ewe lambs found cycling at approximately 1 year of age. Ewe lambs that were heaviest after weaning (LWCI) lost more weight throughout the summer season, were still heavier at the time of laparoscopy, but only $43.4 \%$ were found cycling. Their counterparts that recorded lower rates of live weight loss (LWCII and LWCIII) were sexually more mature based on the proportions of animals cycling, despite lower absolute live weights. Collectively, these results stress the importance of the dynamic component of live weight on the attainment of puberty and sexual maturity in Barbarine ewe lambs. While in Greyface ewes under temperate British conditions, reproductive performance was dependent on both the rate of live weight change and the absolute live weight at mating (Gunn and Maxwell, 1989). For LWCIII ewe lambs, the lower rate of loss of live weight could be the key signal to enhance their LH secretion as a result of a reduced negative feed-back by oestradiol (Rhind and McNeilly, 1986) and this could have accelerated the chain of events leading to puberty and establishment of ovarian cyclic activity (Foster et al., 1985).

Secondly, in the present study, the rate of live weight loss during summer time didn't affect changes in IGF-I and estradiol concentrations during the early follicular phase, the ability to re-ovulate after synchronisation with progestagens and the number of ova shed for those animals that attained puberty. In comparison to other breeds of sheep (Gonzalez-Bulnes et al., 2005, Viñoles, 2003), obtained low concentrations of estradiol could be explained by the low age of the animals in this experiment and also by the synchronisation treatment as ovulatory follicles from sheep treated with progestagens show deficiencies in the secretion of estradiol during the preovulatory phase (Gonzalez-Bulnes et al., 2005). With 


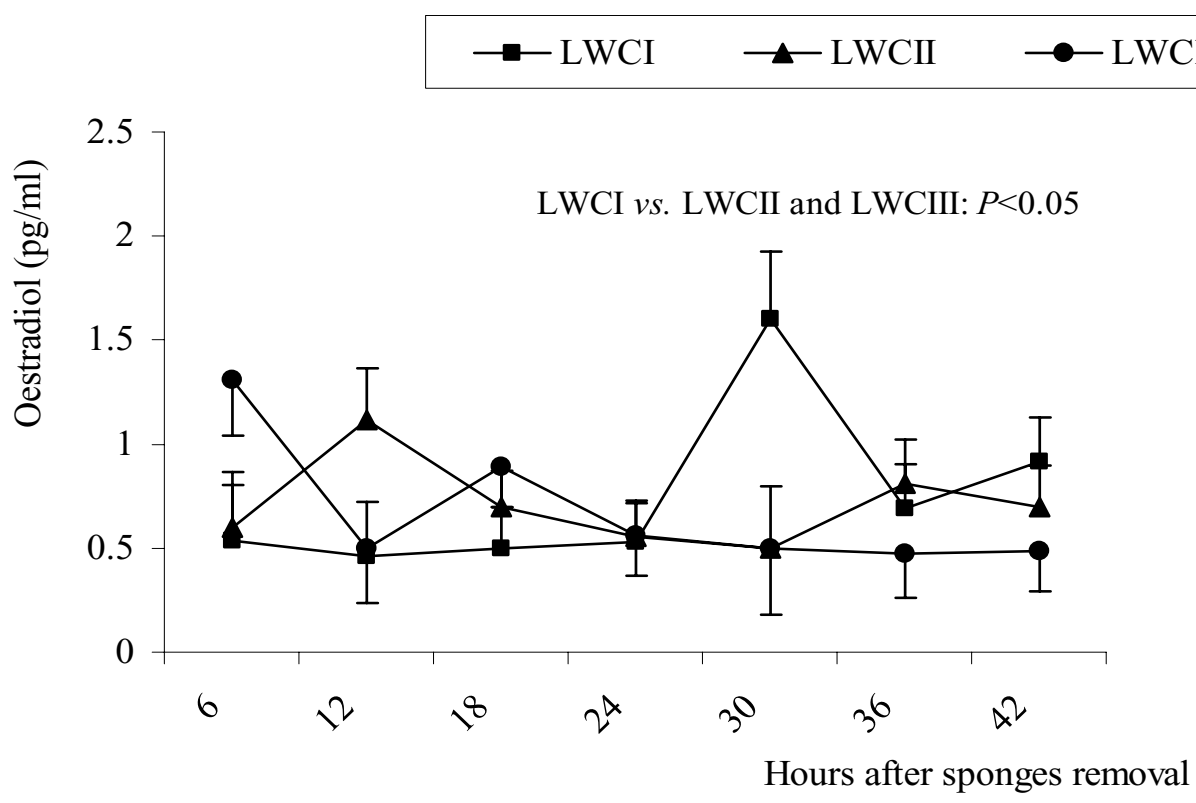

Figure 3. The effect of class of live weight on estradiol concentrations during the follicular phase after synchronization with progestagen intravaginal sponges.

regard to IGF-I concentrations, the absence of differences between ewe lambs in the three classes of live weight over the $42 \mathrm{hrs}$ following sponge removal can be explained by the fact that all the animals ovulated after sponge removal, a finding that is consistent with previous findings by Spicer et al. (1993). They showed that for lines of Finnish sheep with different levels of ovulation rate, the main difference was the significantly lower IGF-I plasma concentrations during the follicular phase of those animals that did not ovulate following synchronisation. However, the same authors observed a significant correlation between plasma IGF-I concentrations and body weights. There was no such relationship in our study despite significant differences in live weights among animals in the three classes at the time of oestrous synchronisation and blood sampling for IGF-I determination. One possible explanation could be related to the overall poor metabolic status of the animals in our study, a consequence of the negative change in live weight throughout the summer season, while the absolute weight at that stage had no influence. Such a hypothesis could also be due to the fact that all the ewe lambs had invariably shed one ovum each after pessary removal. The findings also highlight the fact that for those ewe lambs of the Barbarine breed that attain puberty at the end of the summer season after loosing much body mass, no further consequences of the rate of live weight loss are depicted at the ovarian level.

\section{Conclusion}

Sheep farmers in Central Tunisia are likely to obtain depressed reproductive results if they intend to mate Barbarine females at the end of summer time around puberty particularly in low input systems where the animals are likely to loose much body mass. However, there seem to be important individual differences in the rate of losing weight; a feature that could be exploited in selecting replacement females.

\section{Acknowledgements}

This work was supported by the International Atomic Energy Agency (IAEA) and the Ministry of Scientific Research, Technology and Capacity Building of Tunisia under the framework of the technical cooperation project TUN 5/021. The authors are also indebted to Office de l'Elevage et des Pâturages for providing animals and farming facilities.

\section{References}

Elmes, M., L.R. Green, K. Poore, J. Newman, D. Burrage, D.R.E. Abayasekara, Z. Cheng, M.A. Hanson and D.C. Wathes. 2005. Raised dietary $n-6$ polyunsaturated fatty acid intake increases 2 -series prostaglandin production during labour in the ewe. Journal of Physiology 562: 583-592.

Foster, D.L., S.M. Yellon and D.H. Olster. 1985. Internal and external determinants of the timing of puberty in the female. Journal of Reproduction and Fertility 75: 327-344.

Gonzalez-Bulnes, A., R.M. Garcia-Garcia, V. Castellanos, J. Santiago-Moreno, C. Ariznavarreta and V. Domínguez. 2003. Influence of maternal environment on the number of transferable embryos obtained in response to superovulatory FSH treatments in ewes. Reproduction Nutrition Development 43:17-28. 
Gonzalez-Bulnes, A., A. Veiga-Lopez, P. Garcia, R.M. Garcia-Garcia, C. Ariznavarreta, M.A. Sanchez, J.A.F. Tresguerres, M.J. Cocero and J.M. Flores. 2005. Effects of progestagens and prostaglandin analogues on ovarian function and embryo viability in sheep. Theriogenology 63:2523-2534.

Gunn, R.G. and T.J. Maxwell. 1989. A note on the effect of the direction of live weight change about the time of mating on reproductive performance of Greyface ewes. Animal Production 48:471-474.

Khaldi, G. 1984. Variations saisonnières de l'activité ovarienne, du comportement d'oestrus et de la durée de l'anoestrus post-partum des femelles ovines de race Barbarine: influence du niveau alimentaire et de la présence du mâle. Thèse de Doctorat d'Etat. Université des Sciences et Techniques du Languedoc, Académie de Montpellier.

Martin, G.B., S. Tjondronegoro, R. Boukhliq, M.A. Blackberry, J.R. Briegel, D. Blache, J.A. Fisher and N. R. Adams. 1999. Determinants of the annual pattern of reproduction in mature male Merino and Suffolk sheep: modification of endogenous rhythms by photoperiod. Reproduction, Fertility, Development 11:355-366.

Oldham, C.M. and D.R. Lindsay. 1980. Laparoscopy in the ewe: A photographic record of the ovarian activity of ewes experiencing normal or abnormal oestrous cycles. Animal Reproduction Science 3:119-124.

Rekik, M. and M. Gharbi. 1999. Réponse des races à viande ovines locales en Tunisie à la reproduction en âge précoce. Tropicultura 16-17:64-69.

Rekik, M., N. Lassoued and C. Yacoubi. 2002. Reproductive performances in ewe lambs of the
Queue Fine de l'Ouest breed and their D'Man crosses following synchronisation. Small Ruminant Research 45:75-78.

Rhind, S.M. and A.S. McNeilly. 1986. Follicle populations, ovulation rates and plasma profiles of $\mathrm{LH}$, FSH and prolactin in Scottish blackface ewes in high and low levels of body condition. Animal Reproduction Science 8:301-313.

Romeu, A., I. Molina, J.A. Tresguerres, M. Pla and J.A. Peinado. 1995. Effect of recombinant human luteinizing hormone versus human chorionic gonadotrophin: effects on ovulation, embryo quality and transport, steroid balance and implantation in rabbits. Human Reproduction 10:1290-1296.

Spicer, L.J., J.P. Hanrahan, M.T. Zavy and W.J. Enright. 1993. Relationship between ovulation rate and concentrations of insulin-like growth factor-1 in plasma during the oestrus cycle in various genotypes of sheep. Journal of Reproduction and Fertility 97:403-409.

Statistical Analysis Systems (SAS) Institute, Inc., 1991. User's Guide, version 6.10. SAS Institute, Inc., Cary, $\mathrm{NC}$, USA.

Thimonier, J. and P. Mauléon. 1969. Variations saisonnières du comportement d'oestrus et des activités ovarienne et hypophysaires chez les ovins. Annales de Biologie Animale, Biochimie, Biophysique 9:233-250.

Viñoles, C. 2003. Effect of nutrition on follicle development and ovulation rate in the ewe. Doctoral thesis. Swedish University of Agricultural Sciences, Uppsala.

Wood, P.D.P. 1967. Algebraic model of the lactation curve in cattle. Nature 216:164-165. 